\title{
Enoxaparin Induced Fatal Retroperitoneal Hematoma in Elderly Patient with Acute Coronary Syndrome - Case Report-
}

\author{
Sang-Hee Lee, Jong-Seon Park, Woong Kim, \\ Geu-Ru Hong, Dong-Gu Shin, Young-Jo Kim, Bong-Sub Shim \\ Division of Cardiology, Department of Internal Medicine, \\ Yeungnam University hospital, Daegu, Korea
}

-Abstract-

Anticoagulation and antiplatelet therapy became a cornerstone of the primary treatment strategy in the case of acute coronary syndrome patients which planned to receive medical treatment or percutaneous coronary intervention. The anticoagulation regimen is unfractionated heparins and low molecular weight heparins enoxaparin. Despite of some debates, enoxaparin has replaced unfractionated heparins recently due to its demonstrated advantages. When we encountered acute coronary syndrome patients without contraindication for enoxaparin, it tends to be administered with no hesitation. However, a few patients treated with enoxaparin could be suffered from bleeding complication. Also, in case of bleeding into the retroperitoneal space, the result can be fatal. We report a patient who developed a fatal retroperitoneal hematoma during enoxaparin treatment for acute coronary syndrome.

Key Words : Enoxaparin, Acute Coronary Syndrome, Retroperitoneal Hematoma

Introduction

For the lst decades, enoxaparin has been demonstrated its advantages over unfractionated heparins (UFHs) and has become the most commonly used regimen for anticoagulation. Several large randomized trials showed that enoxaparin is statistically more effective than UFHs. ${ }^{1)}$ Due to its proven efficacy and advantage, we have a tendency to administrate

책임저자 : 박종선, 대구광역시 남구 대명5동 317-1, 영남대학교 의과대학 내과학교실

Tel: (053) 620-3837, Fax: (053) 620-8386, E-mail: jspark@med.yu.ac.kr 
enoxaparin when we encountered acute coronary syndrome (ACS) patients regardless of ongoing debates on its safety. In fact, several fatal bleeding complications have been reported in clinical setting. ${ }^{2)}$ We report a case to raise the awareness to physician that prescribing enoxaparin to elderly ACS patient with comorbidity which can lead to major bleeding.

\section{Case Report}

A 83 year old man was admitted to our hospital due to a chest pain lasted for 10 hours. Initial electrocardiography (ECG) showed ST segment depression on precordial leads and cardiac enzymes were within normal ranges. He was diagnosed as unstable angina pectoris and treated with enoxaparin (subcutaneous injection, $1 \mathrm{mg} / \mathrm{kg} / 12$ hours) as well as aspirin and clopidogrel. At the time of admission, his weight was $50 \mathrm{~kg}$, height was $1.61 \mathrm{~m}$ and BMI was $19.5 \mathrm{~kg} / \mathrm{m}^{2}$. The patient did not have any history of antiplatelet drug or coagulopathies. Admission laboratory values were following: hemoglobin $12.4 \mathrm{~g} / \mathrm{dl}$, platelet count 174000 , creatinine $1.1 \mathrm{mg} / \mathrm{dl}$, glomerular filtration rate (GFR) $52.04 \mathrm{ml} / \mathrm{min}$, prothrombin time 12.1 seconds, and activated partial thromboplastin time 39.8 seconds. On the 3rd day of admission, he underwent percutaneous coronary intervention (PCI) because of a recurrent, continuous angina with tachycardia, but there was no change on a follow up ECG or cardiac enzymes. Coronary angiography revealed focal 85\% diameter stenosis at mid portion of left anterior descending artery and drug eluting stent was deployed with the successful result. However, his symptom was not improved and tachycardia was still ongoing during PCI and even at coronary intensive care unit. His vital sign became more unstable and progressed to impending shock with worsening pain. While repeated cardiac enzymes were still within normal limits however, hemoglobin level was $8.1 \mathrm{~g} / \mathrm{dl}$ at this time. We started fluid resuscitation and suspected hemopericardium however, echocardiography did not show any fluid collection in

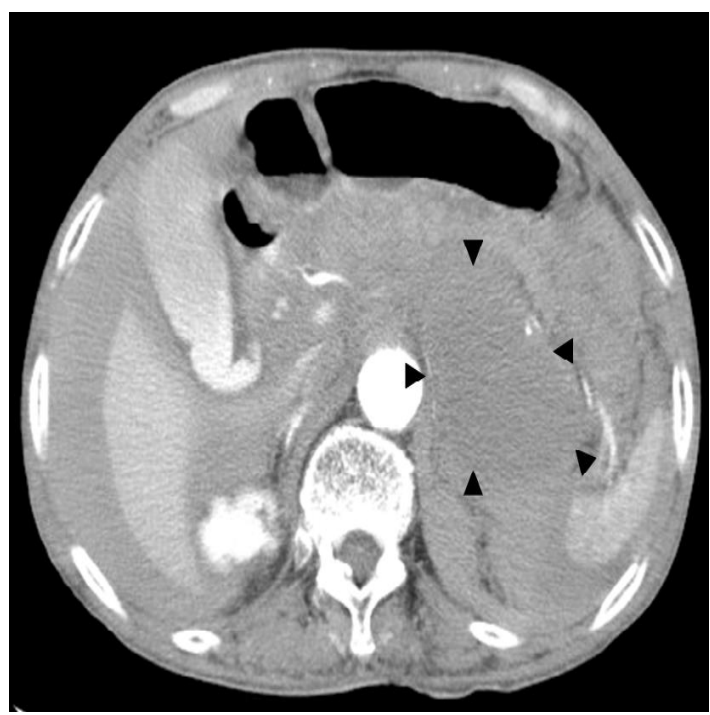

Fig. 1. Abdominal Computed tomography (CT). CT revealed large hematoma at whole abdomen, mainly retroperitoneum. Also, different densities are noted inside hematoma (arrow heads), maybe, which representing different time of bleeding from retroperitoneal space. 
- Sang-Hee Lee $\cdot$ Jong-Seon Park $\cdot$ Woong Kim $\cdot$ Geu-Ru Hong $\cdot$ Dong-Gu Shin $\cdot$ Young-Jo Kim • Bong-Sub Shim -

pericardial space. Although even puncture site of femoral artery was intact, we noticed his hemoglobin level went down to $9.2 \mathrm{~g} / \mathrm{dl}$ in the morning of this event. About 30 minutes later, abdominal pain and distension was newly developed, which was accompanied by cutaneo-mucose paleness, purple-like skin color changes of flank and profound shock. At this time, the patient's hemoglobin level was decreased to $6.1 \mathrm{~g} / \mathrm{dl}$. Abdominal computed tomography $(\mathrm{CT})$ revealed large hematoma in a whole abdomen, mainly retroperitoneum. The hematoma had subtle different densities in some regions of retroperitoneum which seemed to be due to different bleeding time(Fig. 1). But we could not find bleeding focus. Angiography or aortogram could not be performed due to progressive and severe shock. Because vascular injury couldn't be excluded, we conducted exploration. The cause of hematoma was not injuries of aorta or even its branches but diffuse bleeding of retroperitoneal wall. After the exploration was stopped, refractory shock and a bleeding caused his death. Finally, we came to the conclusion that this fatal bleeding was spontaneous and induced by enoxaparin.

\section{Discussion}

For the last decades, enoxaparin has been demonstrated its advantages over UFHs and has become the most commonly used drug for anticoagulation. Because of research data about its efficacy and advantages, we have tendency to use enoxaparin in ACS patients, but the debates about safety still remained." For example, early large clinical studies excluded some diseases such as severe renal impairment, advanced heart failure and used a small sample size of patients with extremely old age (>80 year old), ${ }^{1,34}$ although the most part of the patients with ACS are old age and have several comorbidity. In fact, several fatal bleeding complications, such as abdominal wall hematoma, intrahepatic hemorrhage, psoas hematoma, thigh hematoma, retroperitoneal hematoma and spinal or epidural hematoma have been reported in real world. ${ }^{5)}$ Most of them were old age and had renal dysfunction. Although the absolute number of the reported cases was very small like as conclusion on some studies, those resulted in extremely fatal events. ${ }^{1,6)}$

In the present case, the patient was extremely old age and had reduced GFR. We administrated enoxaparin with antiplatelet drugs. Of course, an antiplatelet drug combined with enoxaparin is not a predictor of major bleeding, $\left.{ }^{1,3}, 7\right)$ but we should have individualized this patient and reduce dose of enoxaparin due to his age or reduced GFR. It is well known that the elimination time of low molecular weight heparin (LMWHs) is delayed in the clinical settings of chronic kidney disease and decreased creatinine clearance rate $(\mathrm{CCR})^{8}{ }^{8}$ CCR of old age are lower than that of young people and $\mathrm{CCR}$ usually overestimates 
GFR. Accordingly, we must consider GFR or creatinine level of elderly ACS patientsreceived anticoagulation therapy. We don't have clear reference, however it seems to be favorable to reduced dose of enoxaparin $(65 \%$ of recommended dose) in patients with renal impairment." Other study, ExTRACT-TIMI 25 trial for ST segment elevation ACS, recommended prolonging interval between doses from every 12 to every 24 hours in older than 75 and $\mathrm{CCR}<30 \mathrm{ml} / \mathrm{min}^{{ }^{9}}{ }^{\text {) }}$ Retroperitoneal hematoma is not diagnosed easily, because manifestation of retroperitoneal hematoma is vary and the diagnosis requires a high index of suspicion. ${ }^{10)}$ In other cases reported previously, we could not diagnose the retroperitoneal hematoma at early state. It was not only because his symptom was limited as chest pain but also we missed laboratory finding at that day morning. Prudent care, most of all, including history taking for comorbidity, physical examination, and repeated test of serum hemoglobin level (even not follow up anti-Xa activity), should not be neglected in cases such as this patient. In our case, we think that the retroperitoneal hematoma may be progressed spontaneously before PCI or clinical presentation. With the findings during exploration, hemoglobin level and CT findings may be the clues for this. We suggest that physician prescribing enoxaparin to elderly ACS patient with combined disease should be aware of the possibility of this major bleeding.

\section{요 약}

급성 관상동맥 증후군 환자에서 약물 치료나 관상동맥 성형술을 시행할 때 항응고 치료와 항혈소판 치료는 일차 치료 전략의 기본이 되 어왔다. 항응고 요법은 unfractionated heparins 과 low molecular weight heparin인 enoxaparin 이 있으며, 근래에는 여러 이점 때문에 enoxaparin 을 흔히 사용한다. enoxaparin의 금기증이 없 는 한 급성 관상동맥 증후군에서는 즉시 사용 하여야 하지만 출혈과 같은 부작용이 발생할 수 있다. 특히 후복강내로 출혈이 발생할 경우 치명적일 수 있다. 저자들은 급성 관상동맥 증 후군으로 enoxaparin을 사용중인 환자에서 관 상동맥 성형술을 시행 후 지속적인 혈색소 감 소가 있는 환자에서 복부 단층 촬영을 통해 후 복강내 출혈을 발견할 수 있었다.

\section{References}

1. Petersen JL, Mahaffey KW, Hasselblad V, Antman EM, Cohen M, Goodman SG, et al. Efficacy and Bleeding Complications Among Patients Randomized to Enoxaparin or Unfractionated Heparin for Antithrombin Therapy in Non-ST-Segment Elevation Acute Coronary Syndromes: A Systematic Overview. JAMA 2004 Jul 7;292(1):89-96.

2. Jeong TK, Jeong GH, Park BS, Ma SK, Kim SW, Kim NH, et al. Dalteparin-sodium associated retroperitoneal hematoma in a patient with diabetic nephropathy. Korean J Med 2003 64:322-7.

3. Collet JP, Montalescot G, Fine E, Golmard JL, Dalby M, Choussat R, et al. Enoxaparin in unstable angina patients who would have 
- Sang-Hee Lee $\cdot$ Jong-Seon Park $\cdot$ Woong Kim $\cdot$ Geu-Ru Hong $\cdot$ Dong-Gu Shin $\cdot$ Young-Jo Kim • Bong-Sub Shim -

been excluded from randomized pivotal trials. J Am Coll Cardiol 2003 Jan 1;41(1):8-14.

4. Spinler SA, Inverso SM, Cohen M, Goodman SG, Stringer KA, Antman EM. Safety and efficacy of unfractionated heparin versus enoxaparin in patients who are obese and patients with severe renal impairment: Analysis from the ESSENCE and TIMI 11B studies. Am Heart J 2003 Jul;146(1):33-41.

5. A Vayá, Y Mira, J Aznar. Enoxaparin-related fatal spontaneous retroperitoneal hematoma in the elderly. Thromb Res 2003 Apr 15;110(1): 69-71.

6. The SYNERGY Trial Investigators. Enoxaparin vs unfractionated heparin in high-risk patients with non-ST-segment elevation acute coronary syndromes managed with an intended early invasive strategy: Primary results of the SYNERGY randomized trial. JAMA $2004 \mathrm{Jul}$ 7;292(1):45-54.

7. Lemos JA, Blazing MA, Wiviott SD, Brady
WE, White HD, Fox KA, et al. Enoxaparin versus unfractionated heparin in patients treated with tirofiban, aspirin and an early conservative initial management strategy: Results from the A phase of the A-to- $Z$ trial. Eur Heart J 2004 Oct 25(19):1688-94.

8. Cadroy Y, Pourrat J, Baladre MF, Saivin S, Houin G, Montastruc JL, et al. Delayed elimination of enoxaparin in patients with chronic renal insufficiency. Thromb Res 1991 Aug 1;63(3):385-90.

9. Antman EM, Morrow DA, McCabe $\mathrm{CH}$, Murphy SA, Ruda M, Sadowski Z, et al. Enoxaparin versus Unfractionated Heparin with Fibrinolysis for ST-Elevation Myocardial Infarction. N Engl J Med 2006 Apr 6;354(14): 1477-88.

10. Gonzalez C, Penado S, Llata L, Valero C, Riancho JA. The clinical spectrum of retroperitoneal hematoma in anticoagulated patients. Medicine 2003 Jul 82(4):257-62. 